\title{
Losses of potassium from grazed dairy pastures
}

\author{
P.H. WILLIAMS', P.E.H. GREGG* and M.J. HEDLEY ${ }^{2}$ \\ 'MAF Technology, Canterbury Agriculture and Science Centre, Lincoln \\ 'Soil Science Department, Massey University, Palmerston North
}

\begin{abstract}
A simple model was used to estimate losses of potassium (K) which occur from a MidCanterbury dairy farm. Analysis of the results shows the role of the dairy cow in causing losses of $\mathrm{K}$ from the farm. The results from this study could be used to refine the estimates of animalinduced losses of $\mathrm{K}$ in the model used by MAF Technology to predict fertiliser recommendations. Such refinements include the incorporation of information on the time that cows spend off the pasture (in the dairy shed, raceway and on feedpads) and the amount of $\mathrm{K}$ lost from urinations. The study suggests that savings in $\mathrm{K}$ fertiliser requirements through reduced losses from dairy farms are best achieved by minimising the time that dairy cows spend off the pasture and avoiding excessive $\mathrm{K}$ concentrations in herbage through heavy rates of $\mathrm{K}$ fertiliser.
\end{abstract}

Keywords potassium, model, potassium cycling, potassium losses, dairy cattle

\section{Introduction}

Losses of potassium $(\mathrm{K})$ are inevitable in grazed dairy pastures. Losses occur because of removal of $\mathrm{K}$ in animal products, transfer of excreta to the dairy shed and raceways and leaching below the depth of effective plant uptake. In many soils these losses can be compensated for by the release of $\mathrm{K}$ from soil minerals, but if pasture production is to be kept at near maximum levels then soil $\mathrm{K}$ levels must be maintained-in the long term by fertiliser-applications.

Data on the fate of $\mathrm{K}$ as it moves through the soilplant-animal cycle in grazed dairy pasture have been collected from commercial North Island dairy farms and used to produce a simple mass balance model which predicts the losses of $\mathrm{K}$ that occur from a dairy pasture (Williams $\boldsymbol{e} t$ al. 1990a). In this paper, the model (known as the $\mathrm{K}$ Loss model) is used to illustrate the extent of $\mathrm{K}$ losses that occur from a typical dairy farm in Mid-Canterbury. The data generated by the model can also be used to suggest ways of improving fertiliser recommendations and reducing $\mathrm{K}$ losses from dairy farms.

\section{Materials and methods}

The 260 ha farm (Mr J. Roadley's property at Dromore, Mid-Canterbury) is on a Lismore stony silt loam soil and is irrigated by the border-dyke system. Mean annual rainfall is $760 \mathrm{~mm}$. The data used in this study were for the 1988-89 season when the stocking rate was 2.9 cows/ha and mean production was $160 \mathrm{~kg}$ milkfat/cow. No $\mathrm{K}$ fertiliser was applied but the farm received $450 \mathrm{~kg}$ superphosphate $/ \mathrm{ha}$. Young stock were grazed off the farm and all silage made was fed back onto the farm.

Information was collected on the herbage $\mathrm{K}$ concentration, stocking rate, animal performance (milkfat production, mean annual milkfat content and mean cow liveweight), length of milking season, time taken to milk cows and number of days the cows spent off the paddocks during wet weather. The other data required in the $\mathrm{K}$ Loss model (e.g., leaching losses) have been estimated from information collected at the nearby Winchmore Irrigation Research Station.

\section{Results and discussion}

\section{Fate of potassium}

The fate of $\mathrm{K}$ as it moves around the soil-plantanimal cycle on the Mid-Canterbury farm is summarised in Figure 1. Throughout the year the dairy cows ingested $241 \mathrm{~kg} \mathrm{~K} / \mathrm{ha}$ in the herbage. Of this, the dairy cows utilised only a small proportion $(6 \%$ or $14 \mathrm{~kg} \mathrm{~K} / \mathrm{ha}$ ) for animal production (i.e., milk and calf production and culled animals), the remainder being excreted in the form of dung and urine (Hutton et al. 1967). A proportion of excreted $\mathrm{K}$ was lost through transfer off the pasture on to raceways and the dairy shed where cows spent an average of 2 hours per day during the 230-day milking season. A further transfer loss occurred during wet periods of the year when cows spent 5 days off the pasture on a stand-off area. A simple calculation using this information shows that over the 12-month period cows spent $6 \%$ of their time off the paddocks. Thus $6 \%$ of the excreta was deposited in these unproductive areas (Williams \& Roberts 1988) which resulted in a loss of $14 \mathrm{~kg} \mathrm{~K} / \mathrm{ha}$ (Figure 1).

Of the $213 \mathrm{~kg} \mathrm{~K} /$ ha returned to the soil, $90 \%$ was in the form of urine (Hutton et al. 1967). During each 


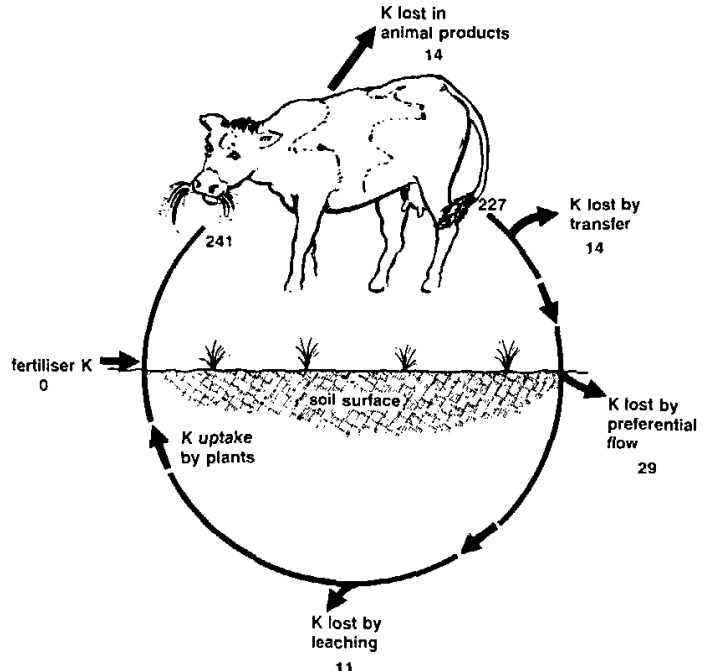

Figure 1 Potassium cycle for a Mid-Canterbury dairy farm (kg K/ha/annum).

urination a proportion of the urine can move down through the soil profile by preferential flow through the soil macropores (Williams et al. 1990b).

Observations on the movement of dairy cow urine labelled with methylene blue dye confirmed that urine can move preferentially through the Lismore stony silt loam soil. Measurements using the tracer technique described in Williams et al. (1990b) on this soil suggest that $15 \%$ of the urine $\mathrm{K}$ (amounting to 29 $\mathrm{kg} \mathrm{K} / \mathrm{ha}$ ) may move beyond a soil depth of $15 \mathrm{~cm}$. Previous trial work on high fertility dairy pastures, with adequate summer moisture, suggests that the majority of $\mathrm{K}$ taken up by herbage growing in urine patches comes from a soil depth of $0-15 \mathrm{~cm}$ (Williams et al. 1989). Pasture plants may be able to extract nutrients from depths greater than $15 \mathrm{~cm}$, particularly during dry periods of the year, but since this is an irrigated pasture such periods are likely to be short term, and so the total amount of nutrients taken up from the subsoil is considered to be a small proportion of the total nutrients taken up over the whole year. In the absence of other information we have assumed that the urine $\mathrm{K}$ that moves below a soil depth of $15 \mathrm{~cm}$ is lost from the dairy farm.

Potassium can also be leached in percolating drainage water after rain or irrigation. The amount leached can be calculated from an estimate of annual drainage per year and a $\mathrm{K}$ concentration of $2 \mathrm{ppm}$ in the drainage water (Campkin 1985).

\section{L osses of potassium}

The total amount of $\mathrm{K}$ lost from the Mid-Canterbury farm was $68 \mathrm{~kg} \mathrm{~K} / \mathrm{ha}$ for the 1988-89 year (Figure 1).

The dairy cow was the major cause of these losses. The losses via animal products, transfer off the pasture and through preferential flow of urine can be directly attributed to the grazing dairy cow and amounted to $84 \%$ of the total loss.
Annual losses of $68 \mathrm{~kg} \mathrm{~K} / \mathrm{ha}$ from this dairy farm may be expected to reduce soil $\mathrm{K}$ levels over time. However, since the Lismore stony silt loam topsoil has a high native soil $\mathrm{K}$ content $(45$ meq. $/ 100 \mathrm{~g}$ total $\mathrm{K}, 0.8$ meq. $/ 100 \mathrm{~g}$ nitric acid-extractable $\mathrm{K}$ and 0.7 meq. $/ 100 \mathrm{~g}$ exchangeable $\mathrm{K}$; Williams \& Haynes 1990 ) and a high K supplying power (due to the presence of layered chlorite clay minerals; N.Z. Soil Bureau 1968), the plant-available soil $\mathrm{K}$ content as measured by the MAF quick test is currently being maintained at high levels (mean quick test of 8 which is equivalent to an exchangeable $\mathrm{K}$ of 0.68 meq. $/ 100$ g).

A comparison of these losses with those from dairy farms in other regions shows a similar trend to those for the Mid-Canterbury farm, in that the dairy cow was the major cause of losses from a dairy farm (Table 1). While this study relates only to $K$, the dairy cow is also responsible for major losses of nitrogen, phosphorus and in some situations sulphur from grazed dairy pastures (Williams et al. 1988,1990b). The greatest single loss of $\mathrm{K}$ in this study was through the preferential flow of urine, with the smallest losses via animal products and leaching caused by rainfall and irrigation.

Table 1 Mean annual losses of potassium from three dairy farms calculated by the K Loss model. Data from Williams et al. (1990a)

\begin{tabular}{lccc}
\hline Location of farm & Waikato & Manawatu & Taranaki \\
\hline Stocking rate (cows/ha) & 2.1 & 3 & 3.5 \\
Production ( $\mathrm{kg} \mathrm{milkfat} / \mathrm{ha})$ & 340 & 450 & 640 \\
Losses of K $(\mathrm{kg} \mathrm{K} / \mathrm{ha})$ & & & \\
Animal products & 10 & 13 & 17 \\
Transfer off the pasture & 16 & 39 & 24 \\
Preferential loss of urine & 29 & 48 & 54 \\
Drainage water & 19 & $\mathbf{9}$ & 11 \\
Total loss & $\mathbf{7 4}$ & $\mathbf{1 0 9}$ & 106 \\
\hline
\end{tabular}

The size of the losses varied considerably between the four farms for which data are presented (Figure I; Table 1). The Mid-Canterbury and Waikato farms had the smallest $\mathrm{K}$ losses. One factor that controls the size of the $\mathrm{K}$ losses is the amount of $\mathrm{K}$ that is cycling through the grazed pasture, which is determined by the herbage $\mathrm{K}$ concentration and pasture production. The Mid-Canterbury farm had the lowest $\mathrm{K}$ herbage concentration of the farms $(2.2 \%)$, and this resulted in a smaller amount of $\mathrm{K}$ being cycled via animals; consequently, losses of $\mathrm{K}$ were smaller. The Waikato farm had the lowest animal production and stocking rate compared with other farms: thus a smaller amount of $\mathrm{K}$ was cycled and consequently losses of $\mathrm{K}$ were lower. Where pasture and animal production are high losses of $\mathrm{K}$ are likely to be higher.

\section{Comparison with MAF model}

Fertiliser requirements can be estimated by assessing $\mathrm{K}$ losses from the farm and the $\mathrm{K}$ supply from the 
soil, the latter being derived from soil type and soil $\mathrm{K}$ content. MAF Technology currently base their fertiliser recommendations on a model which calculates the losses of $\mathrm{K}$ and the supply of $\mathrm{K}$ from the soil for an individual farm (Cornforth \& Sinclair 1984). To date there have been few opportunities to compare the losses predicted by the MAF model with those of an alternative method for estimating $\mathrm{K}$ losses from farms. The data from this study present one such opportunity.

The $\mathrm{K}$ losses from the Mid-Canterbury farm predicted by the MAF model are shown in Table 2. A comparison of these values with those predicted by the K Loss model (Figure 1) shows a number of differences. The MAF model predicted that losses of $\mathrm{K}$ due to transfer of excretal $\mathrm{K}$ off the pasture were much higher than those calculated by the K Loss model. The reason for the difference between the values is that in the MAF model the assumption is made that dairy cows spend $18 \%$ of the year on unproductive areas (Campkin 1985), whereas on the Mid-Canterbury farm the figure was only $6 \%$

Table 2 Losses of potassium from the Mid-Canterbury farm calculated by the MAF model.

\begin{tabular}{lc}
\hline & $\mathrm{kg} \mathrm{K} / \mathrm{ha}$ \\
\hline Animal products & 16 \\
Transfer off the pasture & 64 \\
Preferential loss of urine & 0 \\
Drainage water & 11 \\
Total loss & 91 \\
\hline
\end{tabular}

While the MAF model appears to have overestimated the amount of $\mathrm{K}$ lost due to transfer, the MAF model underestimated the amount of $K$ lost via_leaching by-not-allowing-for the lo ${ }^{-}$ss that occurs during preferential flow of urine through the soil profile. For the Mid-Canterbury farm (Figure 1) this could be the major mechanism for $\mathrm{K}$ losses accounting annually for $29 \mathrm{~kg}$ K/ha.

Similar differences in estimated $\mathrm{K}$ losses between the $\mathrm{K}$ Loss and MAF models have been recorded for other dairy farms (Williams et al. 1990a), suggesting that it is possible to improve the MAF model predictions through consideration of the time that dairy cows spend off the pasture and incorporation of the loss of $\mathrm{K}$ from urinations.

Data collected from the dairy farm in this study (Figure 1) and on other farms (Table 1) show a considerable variation in the animal losses (via animal products, transfer and preferential flow of urine). On a per stock unit basis this range is from 2.9 to $4.7 \mathrm{~kg} \mathrm{~K} / \mathrm{su}$.

The variation is due mainly to differences in management practices between farms (e.g., the time taken to milk the cows and the use of a feed pad). In contrast the MAF model uses a constant value of $4 \mathrm{~kg}$ $\mathrm{K} / \mathrm{su}$ for all dairy farms on flat topography (Cornforth \& Sinclair 1984). If, for example, on the
Manawatu farm a value of $4 \mathrm{~kg} \mathrm{~K} / \mathrm{su}$ is used instead of the $4.7 \mathrm{~kg} \mathrm{~K} / \mathrm{su}$ derived for this farm, then losses and therefore fertiliser requirements are underestimated by $15 \mathrm{~kg} \mathrm{~K} / \mathrm{ha}$. The variation in these animal $\mathrm{K}$ losses shown in this paper indicates that these losses will be more accurate if calculated independently for each individual farm. The information required is readily available from dairy farmers (e.g., animal production data and the length of time the dairy cows spend in the dairy shed).

\section{Reducing potassium losses}

A knowledge of the various losses of $\mathrm{K}$ from a dairy farm is useful for identifying ways of reducing these losses. While little can be done to reduce the loss caused by the preferential flow of urine, it may be possible to reduce the amount of $\mathrm{K}$ that is transferred off the pasture to unproductive areas such as raceways, the dairy shed and feedpads. Methods for achieving this include minimising the time that cows spend in these areas through ensuring an efficient layout of raceways and gateways leading to and from the dairy shed (which minimises the time that the cows spend standing off the paddock before and after milking) and better drainage of land to reduce the need for a feedpad (Williams et al. 1988). The collection and return of effluent from the dairy shed to a large proportion of the farm will also help to reduce losses.

The quantity of $\mathrm{K}$ lost via dairy cows is a function of the amount of $\mathrm{K}$ ingested; therefore the more $\mathrm{K}$ is ingested, the greater are the losses of $\mathrm{K}$. Where herbage $\mathrm{K}$ concentration is above the optimum level for pasture growth $(>2.5 \%$; Cornforth \& Sinclair 1984), reducing $K$ fertiliser rates may reduce the $K$ level-in-the-ingested-herbagnithx affecting pasture production. Applying high rates of $\mathrm{K}$ as split applications will also help to prevent excessive $\mathrm{K}$ concentrations in the pasture.

\section{Conclusions}

Dairy cows were responsible for $84 \%$ of the total losses from a Mid-Canterbury farm. Reductions of these losses may be possible through minimising the time that dairy cows spend off the pasture in the dairy shed, raceways and feedpads and avoiding excessive-concentrations of $\mathrm{K}$ in the herbage through heavy rates of $\mathrm{K}$ fertiliser.

The amount of $\mathrm{K}$ fertiliser required on dairy farms can be predicted more accurately by considering information on the time that cows spend off the pasture and the amount of $\mathrm{K}$ lost during urinations. Since animal-induced $\mathrm{K}$ losses vary between individual farms according to farm management practices, there may be some merit in calculating these losses for individual farms, rather than using one value for all farms which is the current practice where MAF Technology are giving fertiliser recommendatons. 


\section{ACKNOWLEDGEMENTS}

We are grateful to John Roadley and Jeff Morton for providing the data used in this study and Andrea Coppard for chemical analysis of the soil and herbage samples.

\section{REFERENCES}

Campkin, R. 1985. Model for calculating potassium requirements for grazed pastures. NZ journal of experimental agriculture 13: 27-37.

Cornforth, I.S.; Sinclair; A.G. 1984. Fertiliser and lime recommendations for pastures and crops in NZ 2nd edition. Wellington, Ministry of Agriculture \& Fisheries.

Hutton, J.B.; Jury, K.E.; Davies, E.B. 1967. Studies of the nutritive value of New Zealand dairy pastures V. The intake and utilisation of potassium, sodium; calcium, phosphorus, and nitrogen in pasture herbage by lactating dairy cattle. NZ journal of agricultural research 10: 367-388.

New Zealand Soil Bureau 1968. Soils of New Zealand. Part 2. NZ Soil Bureau bulletin 26.

Williams, P.H. Gregg, PE.H. Hedley, M. J. 1990a. Mass balance modelling of potassium losses from grazed dairy pasture. NZ journal of agricultural research 33 . In press.

Williams, P.H.; Gregg, P.E.H.; Hedley, M.J. 1990b. Use of potassium bromide solutions to simulate cow urine flow and retention in pasture soils. NZ journal of agricultural research 33. 489-496.

Williams, P.H.; Haynes, R.J. 1990. Influence of improved pastures and grazing animals on nutrient cycling within New Zealand soils. NZ journal of ecology 13. Inpress.

Williams, P.H.; Hedley, M.J.; Horne, D. J. 1988. The effect of drainage on some aspects of nutrient loss from a silt loam under dairying. Proceedings of the 4th national drainage seminar, Occasional Report No. 9, Soil Science Department, Massey University, Palmerston North: 30-34.

Williams, P.H.; Hedley, M.J.; Gregg, P.E.H. 1989. Uptake of potassium and nitrogen by pasture form urine-affected soil. NZ journal of agricultural research 32: $415-421$.

Williams, P.H.; Roberts, A.H.C. 1988. Estimation of potassium losses from a grazed dairy farm in Taranaki. NZ journal of experimental agriculture 16: 23-27. 